\title{
Juan Carlos Asensio Palacios
}

Escola Superior de Música de Catalunya, Barcelona

\section{Badania nad śpiewem gregoriańskim przed Semiologią gregoriańska i po niej"}

Rozmowa o badaniach nad śpiewem gregoriańskim przenosi nas chronologicznie do XIX wieku, a jednocześnie w bardzo konkretne miejsce: do opactwa św. Piotra w Solesmes we Francji, gdzie w tamtym okresie odradzał się, obok innych zakonnych wspólnot tego kraju, zakon benedyktynów ${ }^{1}$. Francja po rewolucji oraz epoce napoleońskiej pozwalała ponowne osiedlanie się wspólnot monastycznych, te zaś po powrocie kontynuowały tradycję liturgiczną sprzed rewolucji, w nurcie neogallikańskim. Jedynie pragnienie ojca Prospera Guérangera - promotora odrodzenia zakonu benedyktyńskiego we Francji - by dążyć do jedności z rzymskim Kościołem i liturgia, motywowało do poszukiwania autentyczności pradawnej muzyki kościelnej. Początki tej przygody nie były łatwe. „Oficjalny” śpiew gregoriański wykonywany był na podstawie wydań Pusteta. Repertuar mszy bazował na wydaniu Editio Medicea z 1614 roku. Oficjum bazowało natomiast na lokalnych tradycjach opartych na dawnych rękopisach, skorygowanych jednak w uproszczonym stylu, wdrożonym w XVI wieku przez Sobór Trydencki, w przypadku których należało dowieść, że melodie te nie należą do tradycji średniowiecznej. Dom Guéranger formułuje zasadę, która będzie służyć jako podstawa wczesnych badań w zakresie przywrócenia melodiom ich pierwotnej formy:

Tekst został wygłoszony 20 listopada 2018 roku w opactwie benedyktynów w Tyńcu podczas Międzynarodowej Konferencji naukowej Stowo-Melodia - Neuma jako podstawa śpiewu gregoriańskiego zorganizowanej z okazji 50-lecia wydania Semiologii gregoriańskiej (Rzym 1968) oraz 10-lecia powstania Międzyuczelnianego Instytutu Muzyki Kościelnej w Krakowie. Tłumaczenie: Mateusz Zimny.

1 P. Combe, Histoire de la Restauration du Chant Grégorien d'après des Documents Inédits. Solesmes et l'Édition Vaticana, Solesmes 1969. Nie będę mówił o pracach AISCGre i o wydaniach Graduale Novum, ponieważ jest to temat innego wystąpienia. 
Jedynie wtedy możemy być pewni, że odnaleźliśmy gregoriańską frazę danego utworu w stanie pierwotnym, gdy rękopisy z kilku klasztorów oddalonych od siebie zawierają ten sam zapis².

Tymi słowami rozpoczęła się przygoda, która przez kolejne dekady miała doprowadzić do kwerendy rękopisów w różnych europejskich bibliotekach i archiwach instytucji, tak świeckich, jak i kościelnych, by zlokalizować i sfotografować kodeksy, przesłać ich kopie do opactwa, a tam pracować nad nimi w celu przywrócenia pierwotnych melodii. Kluczowymi postaciami u początku tej pracy byli dom Paul Jausions ${ }^{3}(1834-1870)$ i dom Joseph Pothier (1835-1923) ${ }^{4}$. Być może to oni pierwsi rozpoczęli kształtowanie stylu śpiewu, który od jakiegoś już czasu miał już swoje teoretyczne uzasadnienie w Methode raisonné du-Plain Chant napisanej przez przyjaciela opactwa, kanonika Augustina Gonthiera, który postulował:

zasadą, która określa wszystkie inne zasady, jest to, że poza czystą melodią śpiew jest inteligentnym czytaniem - lekturą z prawidłowym akcentowaniem, odpowiednią prozodią i właściwym frazowaniem ${ }^{5}$.

Przyjęcie własnego stylu śpiewu różniącego się od tego, który pozostawał pod wpływem muzyki teatralnej, było jedną z pierwszych idei dotyczących recytacji psałterza w liturgii godzin. Wobec przedwczesnego odejścia dom Jausionsa kontynuację procesu transformacji stylu chorałowego opartego na przywracaniu długich melizmatów, które zostały usunięte przez XVI-wieczne wydania, zlecono dom Pothierowi. W swojej książce Les mélodies grégoriennes. ${ }^{6}$ Pothier, choć koncentruje się na przedstawieniu metody, która posłużyła mu w odnowieniu śpiewu, stwarza podstawy teoretyczne pod to, czym był już styl oratoryjny Solesmes. Lata później zostanie on przekształcony przez dom Mocquereau według owych

2 P. Guéranger, Institutions Liturgiques, vol. I, 1840, Paris- Bruxelles, s. 306.

3 Złożył profesję w Solesmes 29 września 1856 roku. Wykonał pierwsze kopie rękopisów oraz pierwsze tabele dla przyszłej Paléographie oraz w celu przygotowania Liber Graduali wspólnie z ojcem Pothierem, opracował także Directorium chori (1864), który stał się pierwszym dziełem „odnowy gregoriańskiej” w Solesmes.

4 Złożył profesję w Solesmes 1 maja 1860 roku. W 1880 opublikował Les mélodies gregoriennes d'après la tradition, w którym zaprezentowane zostały wzorcowe metody pracy odnowy, a także Liber Gradualis (1883), do którego kilka lat później dołączono Antiphonale, Processionale oraz Liber Responsorialis.

5 Ch. A. Gontier, Méthode raisonnée de plian-chant, Le Mans 1859, s. 14.

6 J. Pother, Les Mélodies Grégoriennes d'après la tradition, Solesmes 1880. 
skomplikowanych zasad rytmów dwudzielnych i trójdzielnych, arsis i tesis, ictus (dziś termin błędny), przedstawionych w wielu tekstach, które uwieńczone zostaną publikacją Le nombre musical. Aby móc jednak opublikować Liber Gradualis (1883), Joseph Pothier nabrał wcześniej ogromnego doświadczenia, własnoręcznie kopiując rękopisy i opracowując tonariusz opierający się na rękopisie z Montpellier $\mathrm{H} 159^{7}$.

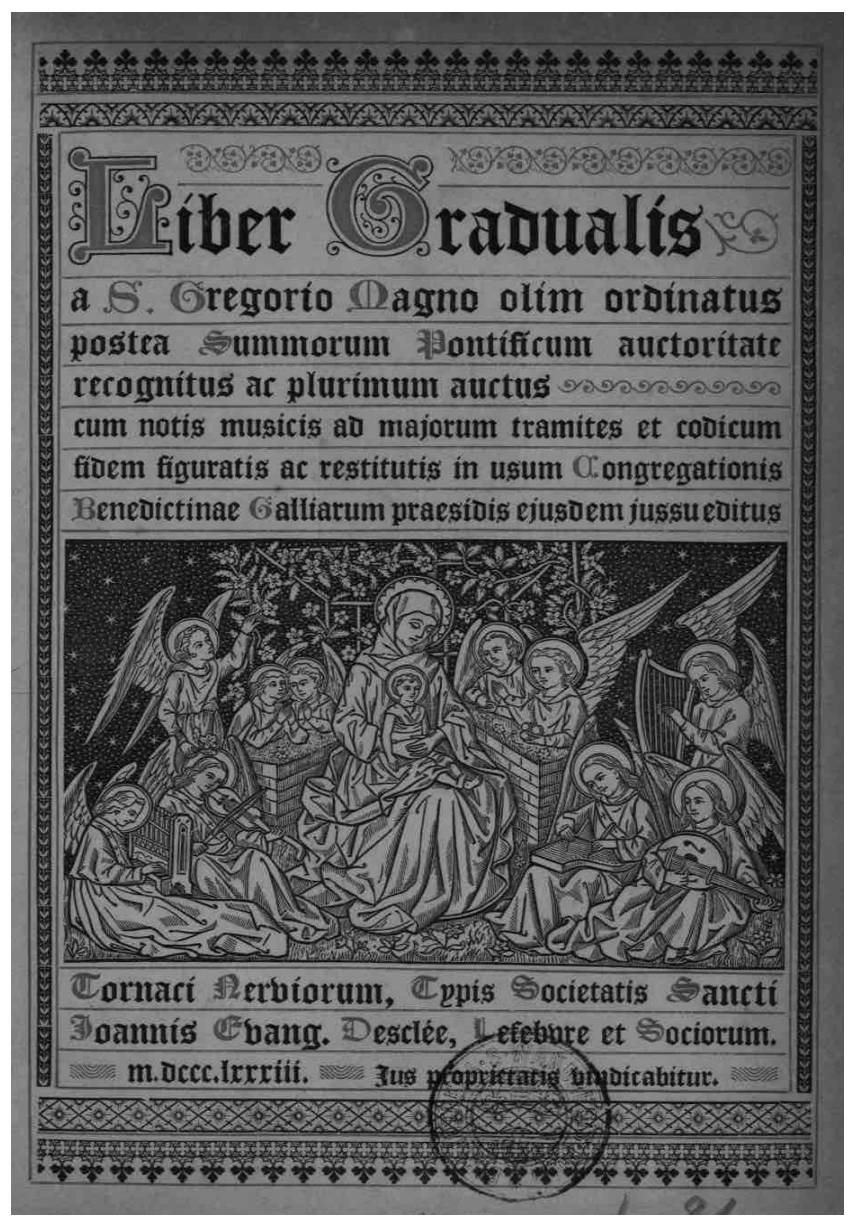

Zdjęcie 1. Liber Gradualis ad usum dom Pothier

7 Materiał ten znajduje się dzisiaj w archiwum opactwa Saint Wandrille, którego opatem był Pothier. Za informację o tym oraz zdjęcia dziękuję Jean-Pierre’owi Noisseux. 


\title{
PALÉOGRAPHIE M U S I C A L E
}

FAC-SIMILES PHOTOTYPIQUES

DES PRINCIPAUX

\author{
MANUSCRITS DE CHANT \\ GRÉGORIEN, AMBROSIEN, MOZARABE, GALLICAN \\ publié par les Bénédictins de l'Abbaye de Solesmes
}

SOLESMES

IMPRIMERIE SAINT-PIERRE

I $889-1: 4^{\circ}$

Zdjęcie 2. Okładka pierwszego tomu Paléographie musicale

Bezpośrednia obserwacja ugrupowań neum w rękopisach doprowadziła go do uszanowania tych samych grup, które później posłużyły do opracowania innych hipotez interpretacyjnych. Sam Pothier przywraca formy graficzne utracone w wydaniach w poprzednich stuleciach - na przykład formę graficzną quilismy i jej pochodne lub bogactwo likwescencji w wielu jej odmianach - wzbogacając tym samym pierwsze edycje z Solesmes o aspekt, którego nigdy wcześniej nie miał śpiew gregoriański: konwencjonalną notację kwadratową na czterech liniach, ale zawierającą w prostym użytkowym formacie drukowanym niektóre znaki pochodzące z dawnych rękopisów, z którymi szybko zaznajomili się mnisi.

W odnowę chorału włączył się młody André Mocquereau, który wstąpił do opactwa (choć na dłuższą metę spowodowało to problemy, i to tak poważne, że doprowadziły one do rozłamu wśród biorących udział w tych wydarzeniach) i był pozytywnie nastawiony do publikacji źródeł wykorzystywanych przez mnichów w ich pracach. Tak więc w 1889 roku ukazał się pierwszy tom Paléographie musicale, który stopniowo udostępniał zainteresowanym źródła wykorzystywane 
do już ukończonego Atêlier de Paleógraphie w naukowym procesie odnowienia chorału ${ }^{8}$.

Fakt, że mnisi uznali za konieczną publikację tych źródeł, był wynikiem krytycznych głosów, które z różnych powodów podniosły się po publikacji ich pracy. Coraz częściej zdawano sobie sprawę, że podstawową składową ich pracy było nie tylko odzyskanie ,autentycznych melodii”, ale także wypracowanie własnego stylu interpretacji, którym w tamtym momencie zaczynali się różnić obaj zaangażowani w pracę mnisi. Podczas gdy dla dom Pothiera rytm oratoryjny (w stylu sylabicznym, a nawet melizmatycznym) był wystarczający do osiągnięcia dobrego wykonania, jego młodszy współpracownik, badając neumy, próbował odnaleźć naukowe argumenty dające podstawy dla stylu interpretacji opartej na sztucznych kombinacjach podstawowych rytmów dwu- i trójdzielnych, które stwarzałyby konieczność umieszczenia dodatkowych znaków (ictus, epizema) w notacji wywodzącej się z idei dom Pothiera. Także dodanie epizem (przypomnijmy, że ictus był nazywany również epizemą poziomą), które znajdują się w nowożytnej notacji kwadratowej, i pojawienie się ich w niektórych zapisach - w innych zapisach nutowych wystarczała modyfikacja znaku lub dodanie liter - nadawało wartość quasi-menzuralną, która podwajała wartość czasu w nutach oznaczonych znakiem epizemy. Kolejną cechą charakterystyczną wprowadzaną wraz ze stylem dom Mocquereau było systematyczne stosowanie zasady arsis-thesis w połączeniu z kombinacją rytmów dwu- i trójdzielnych. Zabieg ten przedstawiony był w sposób ogólny we wstępie do niektórych tomów Paléographie, a zwłaszcza w Le nombre musicale ou rhitmique gregorienne opublikowanej w dwóch tomach ${ }^{9}$. Nie powinniśmy się jednak ograniczać wyłącznie do Solesmes Pothiera i Mocquereau.

W samym zakonie pojawiła się krytyka stylu śpiewu, który był oparty zarówno na tym wypracowanym przez Pothiera, jak i na połączeniu arsis-thesis Mocquereau, znanej również jako ekwalizm. Dom Jules Jeannin (1866-1933), wybitny znawca niektórych tradycji śpiewu wschodniego, bazując na tej wiedzy, bronił swych postulatów menzuralistycznych ${ }^{10} \mathrm{w}$ opozycji do wolnych rytmów mnichów z Solesmes. W 1926 roku Jeannin pisze, że „estetyka solesmeńska w tym,

8 Pierwszy tom ukazał się w 1889 roku, jednak w roku 1888 wydany został Prospectus skierowany do ewentualnych prenumeratorów: Paléographie Musicale. Les Mélodies Liturgiques ou recueil de Fac-similés phototypiques des principaux manuscrits de chant grégorien, ambrosien, gallican, mozárabe, avec préface explicative publiée par les Révérends Pères Bénédictins de l'Abbaje de Solesmes, Solesmes 1888.

9 Wydany przez Desclée w 1908 roku tom pierwszy, a w roku 1927 tom drugi, opracowany we współpracy z ojcem Josephem Gajardem.

10 Études sur le rhytme grégorien, Lyon 1925. 


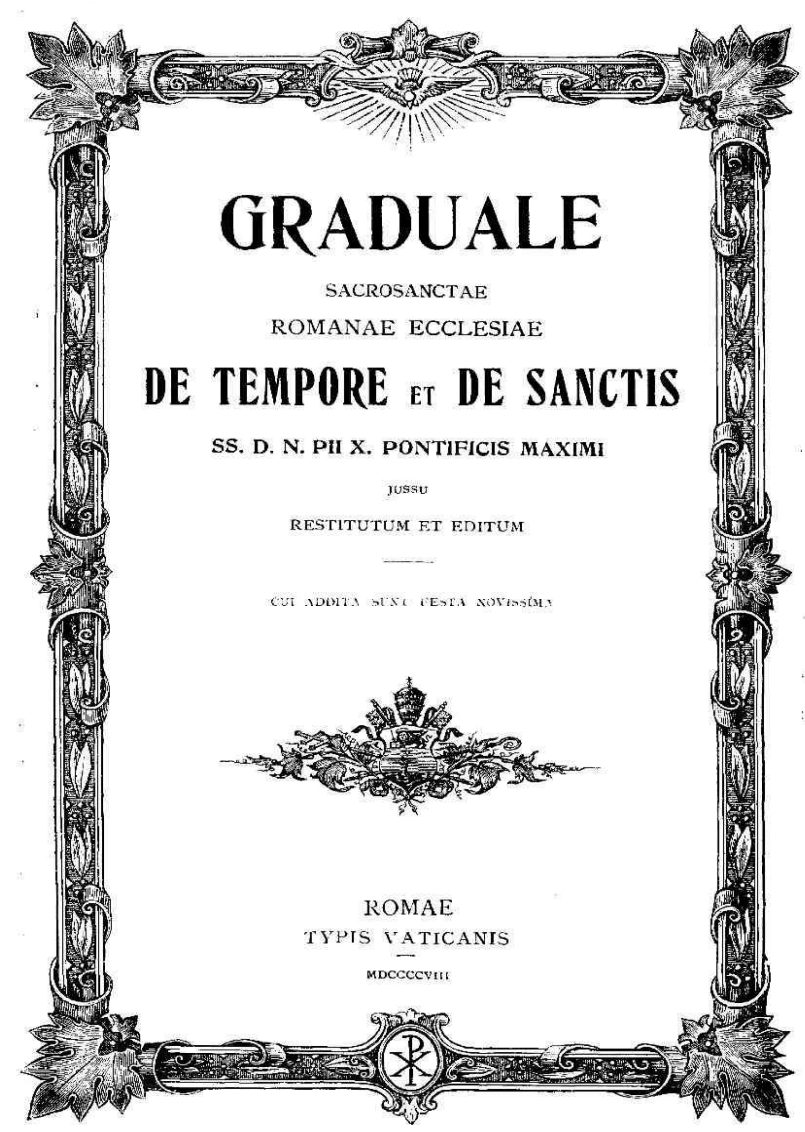

Zdjęcie 3. Okładka Graduale Romanum (1908). Editio Vaticana

co odnosi się do charakteru akcentu łacińskiego, jest dokładnie przeciwieństwem estetyki średniowiecza" ${ }^{11}$. Jego tezy, dzielone częściowo przez innych gregorianistów, takich jak Peter Wagner czy jezuita Jan W. A. Vollaerts ${ }^{12}$, spotkały się ze szczegółową odpowiedzią w pismach dom Mocquereau ${ }^{13}$. Nie bez pewnych kontrowersji prace mnichów z Solesmes zostały wsparte przez motu proprio Tra le

11 Dom J. Jeannin, Mélodies Liturgiques Syriennes et Chaldéenes Paris, Leroux 1926, s. 221.

12 Rhytmic Proportions in Early Medieval Eclesiastical Chant, Leiden 1956 (2a ed. 1960).

13 Examen des critiques dirigéés par Dom Jeannin contre l'École de Solesmes, Solesmes 1926; odpowiedź ze strony Jeannina w Rhytme Grégorien, Réponse à Dom Mocquereau, Lyon 1927. 


\section{ANTIPHONALE MONASTICUM PRO DIURNIS HORIS}

JUXTA VOTA RR. DD. ABBATUM CONGREGATIONUM CONFEDERATARUM ORDINIS SANCTI BENEDICTI

\section{A SOLESMENSIBUS MONACHIS}

\section{RESTITUTUM}

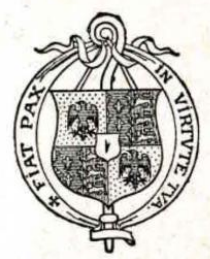

TYPIS SOCIETATIS S. JOANNIS EVANGELISTE DESCLÉE ET SOCII

S. Sedis Apostolicx et S. Rituum Congregationis Typographi

PARISIIS, TORNACI, ROMAE.

1934

Prtited in Belgiun.

sollecitudini świętego papieża Piusa X z 22 listopada 1903 i pośrednio zalecano naśladowanie ich stylu śpiewu. Sam dom Pothier jako przewodniczący Komisji Watykańskiej faktycznie odpowiedzialnej za realizację oficjalnych wydań rzymskich Kyriale (1905) i Graduale (1908) wykorzystał jako metodę pracy interpretację melodii różnych zapisów Kyrie, aby osiągnąć zgodność w odczycie w przypadku ewentualnych różnych wersji ${ }^{14}$.

14 Cytowany w: K. Bergeron, Decadent Enchantments. The Revival of Gregorian Chant at Solesmes, Berkeley 1998. 


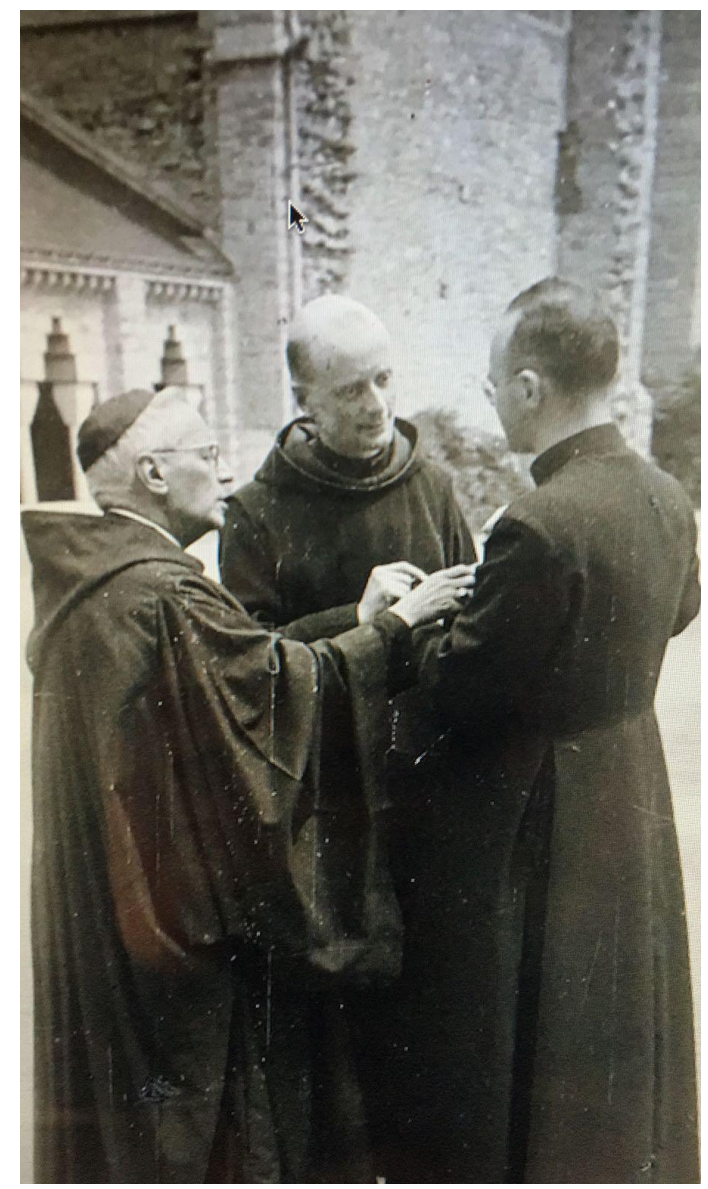

Zdjęcie 5. Dom Cardine (w środku), opat Suñol (po lewej) i Luigi Agustoni (po prawej)

Po ukazaniu się drukiem wydania watykańskiego stopniowo wprowadzano sposób wykonania naśladujący zakonników. Model zaczął się rozprzestrzeniać dzięki wytężonej pracy byłego kierownika chóru Solesmes w latach 1914-1970, a także nadzorującego wydania zamówione przez Rzym dom Josepha Gajarda (1885-1972). Jako kierownik chóru w Solesmes - przebywający także na uchodźstwie w Quarr Abbey na Isle of Wight, skąd powrócił ostatecznie w 1922 - musiał stawiać czoła niekończącej się krytyce wobec metody solesmeńskiej.

Organizowany w Paryżu w grudniu 1922 roku Kongres Muzyki Sakralnej i wykonanie zorganizowane tam przez dom Gajarda ułatwiło wprowadzenie metody Solesmes nie tylko we Francji, ale także poza jej granicami. Po śmierci dom 
Mocquereau (18 stycznia 1930) Gajard został mianowany dyrektorem Atêlier de Paléographie musicale, czego pierwszym owocem była publikacja Antiphonale Monasticum (1934).

Wydanie to osiągnęło wysoki poziom w prezentacji gotowych form graficznych, zgodnych ze średniowiecznymi manuskryptami. Pojawiły się znaki graficzne, które odróżniały grupy strophicus od bivirgi lub trivirgi, wraz z oriscus jako znakiem graficznym różnym od pozostałych neum. Od 1930 roku chór mnichów z Solesmes, kierowany przez dom Gajarda, wykonywał serię zapisów fonograficznych, które rozpowszechniały jego styl po całym świecie, a od 1950 roku regularne nagrania stały się jeszcze częstsze.

I to właśnie w latach po śmierci dom Mocquereau, gdy Gajard konsoliduje szczególny styl śpiewu gregoriańskiego, wstępuje do klasztoru młody Normandczyk - Eugène Cardine. Ma solidne muzyczne wykształcenie zdobyte przed wstąpieniem do klasztoru, podobnie jak inni mnisi wcześniej zajmuje się w klasztorze muzyką. Przez pierwszych kilka miesięcy Cardine nie zna jeszcze metody dom Mocquereau, ale z czasem oswaja się z nią oraz ze sposobem interpretacji dom Gajarda. W 1940 roku, trudnym czasie z powodu nadchodzących wydarzeń, zostaje pierwszym kantorem scholi i stopniowo zaczyna uczestniczyć w pracach nad Paléographie.

Cardine'owi powierzono zadanie indeksowania i opracowania sekwencji zawartych w rękopisach, a także badanie różnych propriów, które pojawiły się w kodeksach. Później zaczął być odpowiedzialny za prace nad edycją krytyczną Graduale. $\mathrm{Z}$ tych czasów zachował się swego rodzaju dziennik, notatki dom Cardine’a na temat czynności, które zakonnicy wykonywali w tym projekcie. Ze względu na ich ciekawą treść cytuję poniżej te zapisy znajdujące się w archiwum Paléographie:

\section{Sprawozdanie dom Cardine'a, w którym prosi dom Coziena o zgodę na przygotowanie krytycznej edycji Graduatu}

Dom Cardine i dom Hourlier odwiedzają biblioteki ${ }^{15}$.

W tym okresie dom Froger odnawia teczki z rękopisami z pomocą brata

Augustina.

Poszukiwanie wariantów w celu ich analizy

(D. Cardine, D. Froger D. Hourlier D. Huglo...).

Fiszki wariantów wybranych z 300 lub 400 graduałów.

D. Cardine i D. Froger,

15 Colección de papeles de la sale de la Palèographie Musicale, bez klasyfikacji. 
później D. Benoit-Castelli, D. Combe (praca wykonana dwukrotnie).

D. Huglo w tym czasie tworzy fiszki graduałów.

D. Poras włącza się w prace (D. Combe także wykonuje fiszki cf. infra t.

2. Les sources).

Porównanie rękopisów według ich wariantów (las regletas itd.).

D. Cardine, D. Froger - następnie D. Benoit-Castelli i D. Combe.

Wydanie tomu 2. Les sources

Przedmowa, nadzór D. Gajard. D. Combe przygotowuje maszynopis.

D. Benoit-Castelli i D. Poras analizują listy Alleluia (?)

D. Bentzmann w tym czasie tworzy fiszki z kalendarzy.

D. Froger przygotowuje różowe fiszki: repertuar mszy.

Tabele Graduatu (patrz zdjęcia, przyp. J. C. A.).

D. Rullon (Cha, Lan, Ben 1-2).

D. Benoit-Castelli (D. Combe (Dijon Clu 1-2 ... V /. z Ofertoria od cza-

su Epifanii. Cantica.

D. Desportes (Gal 1, Klosterneuburg).

Śmierć o. Benoit Castelli w 1964 i D. Desportesa w 1973.

D. Combe kończy tabelę (?), w szczególności (?) V/. z Ofertoria od 6 stycznia / oraz tabele Cantica z Wielkiej Soboty.

Przygotowanie vol. 1 i 2 tomu IV.

Praca D. Frogera

D. Combe opracowuje fiszki w formie maszynopisu (150 wariantów)

Nie jest więc zaskoczeniem, że z całym tym bagażem wiedzy, jaki gromadził dzięki swojej pracy i tej realizowanej przez współbraci, Cardine był gotów rozpocząć rewolucję, która wpłynęła nie tylko na śpiew gregoriański i jego interpretację, ale również na perspektywę tego, jak podchodzić do badań zapisów nutowych - i to nie tylko tych pierwotnie gregoriańskich. Chociaż prace nad wydaniem krytycznym rozpoczęły się wcześniej, w 1950 roku w „Revue Grégorienne” dom Cardine opublikował pierwsze wyniki badań, które znalazły oddźwięk także w innych publikacjach ${ }^{16}$. Niemniej już przed rokiem 1950 poświęca się temu, co stanie się jego głównym dziełem: badaniem neum w celu wyciagnnięcia $\mathrm{z}$ ich zapisów wniosków pomocnych dla interpretacji. Jako przykład cytuję niewielką listę jego prac poprzedzających publikację Semiologii gregoriańskiej z 1968 roku:

16 L'édition critique du graduel. Nécessité, avantages, method, „Revue Grégorienne” (1950) 29, s. 202-208. Ten sam tekst został zaprezentowany i opublikowany w: Atti del Congresso internazionale di Musica Sacra, (Roma 1950), Tournai 1952, s. 187-191. Później opublikowany w: Regarding the Critical Edition of Graduale, „The Gregrorian Review”, (1958) 5/1, s. 21-30. 


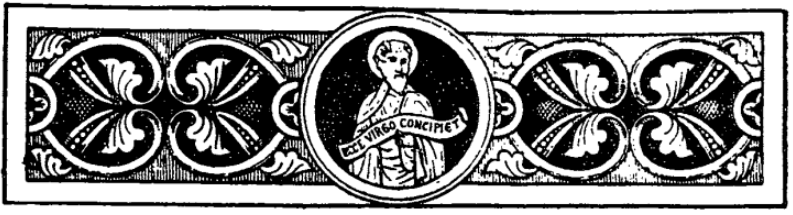

\section{PROPRIUM DE TEMPORE}

\section{Dominica prima Adventus.}

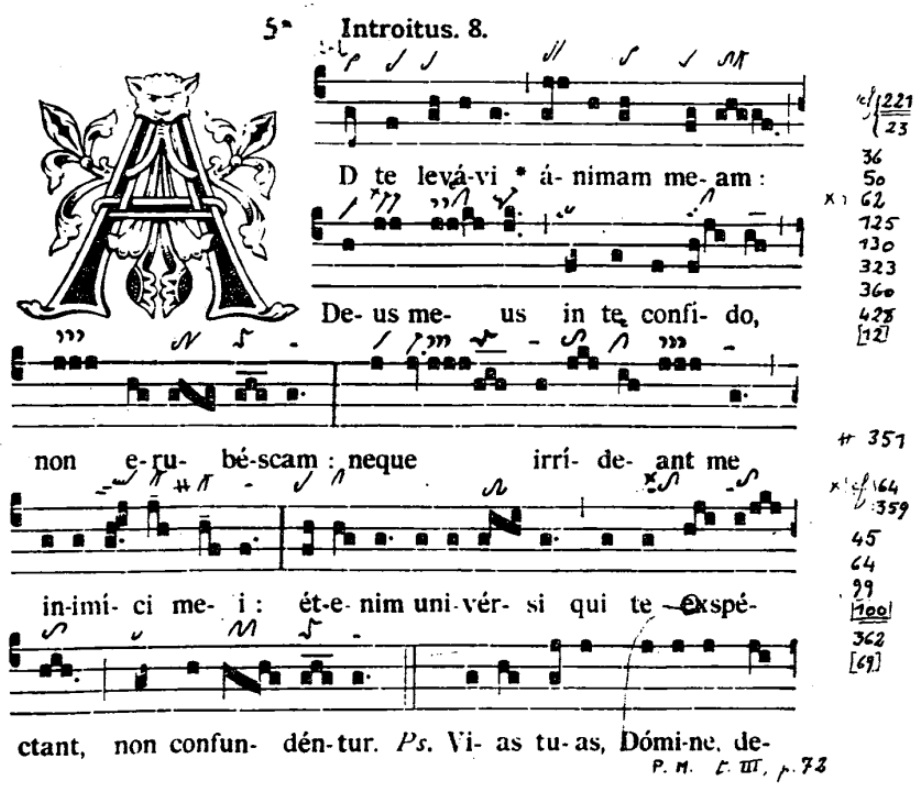

Zdjęcie 6. Pierwsza strona Graduel Neumé dom Cardine'a (1966)

1. Signification de la désagrégation terminale, „Revue Grégorienne” (1952) 31, s. $55-65^{17}$.

17 Opublikowany później jako Il significato della disgregazione terminale del neuma, w: Fonti e paleografia del canto ambrosiano, ed. M. Huglo, L. Agustoni, E. Cardine, E. Moneta-Caglio, Milano 1956, s. 207-219 (Archivio Ambrosiano, 7). 
2. Paroles et mélodie dans le chant grégorien, „Bollettino degli Amici del PIMS" (1954) 6/3, s. 1-9.

3. Neumes et rythme, w: Actes du 3e Congrés Intenational de Musique Sacrée, (Paris, juillet 1957), Paris 1959, s. 264-276, opublikowane później jako Neumes et rythme. Les coupures neumatiques, „Études Grégoriennes” (1959) 3, s. 145-154, na nowo zredagowane w: „Neumes et Rythme”, b.r.w., 14 .

4. Preuves graphiques du príncipe des “coupures” dans les neumes, „Études Grégoriennes" (1961) 4, s. 43-54 i 6 planszy.

W 1966 roku w Solesmes zostaje opublikowany Graduel neumé. Prawdą jest, że idea przepisywania neum ze starych rękopisów w samej księdze śpiewu lub do egzemplarza służącego nauce nie była czymś nowym. Pothier i Mocquereau pozostawili po sobie interesujące przykłady, które dziś przechowywane są zarówno w archiwum Saint Wandrille, jak i w Paléographie, ale krytyczny aparat notatek, konkordancji, wyjątków, ciekawych przypadków i innych adnotacji czynią z Graduel neumé nieodzowny środek do zrozumienia nie tylko idei dom Cardine'a, ale także jego metody pracy.

Wybranym zapisem była notacja z Sankt Gallen, już wtedy analizowana i lepiej znana. Zobaczymy później, jak dom Cardine poszerzy spektrum badań notacyjnych o inne zapisy dzięki pracom doktorskim, które promował po nominacji na profesora w Papieskim Instytucie Muzyki Kościelnej (PIMS).

W 1967 roku ukazuje się jego Paleografia gregoriana, 1, Note raccolte dalle lezioni tenute da dom Eugène Cardine ${ }^{18}$, która w rzeczywistości jest pierwszą częścią Semiologii gregoriańskiej, wydanej we współpracy z Godehartem Joppichem i domem Rupertem Fischerem ${ }^{19}$. Tekst ten stanie się podstawą Semiologii, której wydanie zostało wznowione w 1979 już bez podtytułu „część pierwsza”, ponieważ „część druga” nigdy nie miała się ukazać. Wydanie francuskie ukazało się w nr. 11 (s. 1-158) „Études Grégoriennes” (1970) pod tytułem Sémiologie grégorienne w tłumaczeniu M. Marie Elisabeth Mosseri ${ }^{20}$.

W 1969 roku Cardine opublikował w „Études Grégoriennes” (nr 10) tekst Neume, a rok później opracowanie Primo anno di canto gregoriano z powodzeniem

\footnotetext{
18 Wydana nakładem PIMS, Rzym, 1967, 49 stron.

9 Wydana nakładem PIMS, Rzym, 1968, nr 1.

20 Tekst ten odniósł ogromny sukces bez precedensu w zakresie tłumaczeń w świecie muzykologii. Został przetłumaczony na japoński (1979), angielski (1982), hiszpański (1982), portugalski (1989), holenderski (1991), koreański (1966), kataloński (1997), polski (2000), niemiecki (2003), a później także norweski.
} 
tłumaczone na inne języki ${ }^{21}$. Jego twórczość rozwijała się nie tylko w zakresie pracy własnej, ale także dzięki promowaniu prac dyplomowych i rozpraw doktorskich, które w dużym stopniu w zaledwie kilka lat dokonały prawdziwej rewolucji w zakresie metody interpretacji. Oto jedno z najważniejszych osiągnięć Semiologii: nie była ona tylko teoretycznym opisem, ale jej zasadniczy cel - właściwa interpretacja neum - był widoczny, choć z różnym skutkiem, od samego początku.

Jaki wpływ na badania naukowe i ich aspekt wykonawczy miała zatem praca dom Cardine’a za jego życia i po śmierci? Z pewnością publikacja Semiologii i jej różnych tłumaczeń umożliwiła - wcześniejsze czy późniejsze - poznanie hipotez dom Cardine’a w różnych miejscach na świecie. Należy powiedzieć, że rok wydania Semiologii zbiega się z momentem „wrażliwym liturgicznie” dla gregoriańskiego śpiewu, głównie z powodu błędnych interpretacji Sacrosanctum concilium Soboru Watykańskiego II, bo chociaż - jak sam dokument SC głosi - śpiew gregoriański pozostał „śpiewem własnym Kościoła rzymskiego”, prawdą jest, że od tego momentu powoli zaczął być on odsuwany w cień i ustępował miejsca kompozycjom w językach narodowych. Choć na przestrzeni lat sytuacja stawała się niepokojąca, pozostaje faktem, że zainicjowanie badań śpiewu gregoriańskiego przez instytucje o charakterze wyłącznie edukacyjnym, których celem nie było praktyczne wykonywanie chorału, a tym bardziej przywracanie chorału do użytku w kontekście religijnym, spowodowało, że badania, zwłaszcza nad neumami, rozwinęly się w rzadko spotykany sposób. Dekada lat 70 . i początek lat 80 . miały kluczowe znaczenie dla rozwoju tych badań i dla ich praktycznej interpretacyjnej w niektórych zespołach. Były to zazwyczaj niezakonne zespoły profesjonalnych lub półprofesjonalnych kantorów (tak mężczyzn, jak i kobiet) zainteresowanych odkryciami dotyczącymi neum i tym, jak na podstawie tych badań można by osiągnąć wykonanie jeszcze doskonalsze. Chórowi zakonnemu - i tutaj Solesmes stanowi najlepszy przykład - z wieloletnim doświadczeniem w śpiewie i w stylu oratoryjnym narzuconym metodą solesmeńską nie było łatwo zmienić wypracowany przez lata styl śpiewu i zasady, które ułatwiały zrozumienie konkretnego sposobu śpiewania. Zapomnieć o tym wszystkim i nauczyć się znaczenia neum w sposób quasi-naukowy byłoby dla zakonników, w większości niemających wykształcenia muzycznego, zadaniem prawie niemożliwym. Kierownicy chórów różnych instytucji, choć zainteresowani wynikami badań, często poddawali się, nie zdoławszy zmienić stylu śpiewu w swoich klasztorach. Chociaż jako muzycy

21 Rzym 1970, 68 stron. Tłumaczono na francuski (1975), holenderski (1979), portugalski z Brazylii (1984, wznowiony w 1989), angielski (1988), hiszpański (1990), norweski (1996) i japoński (2002). 


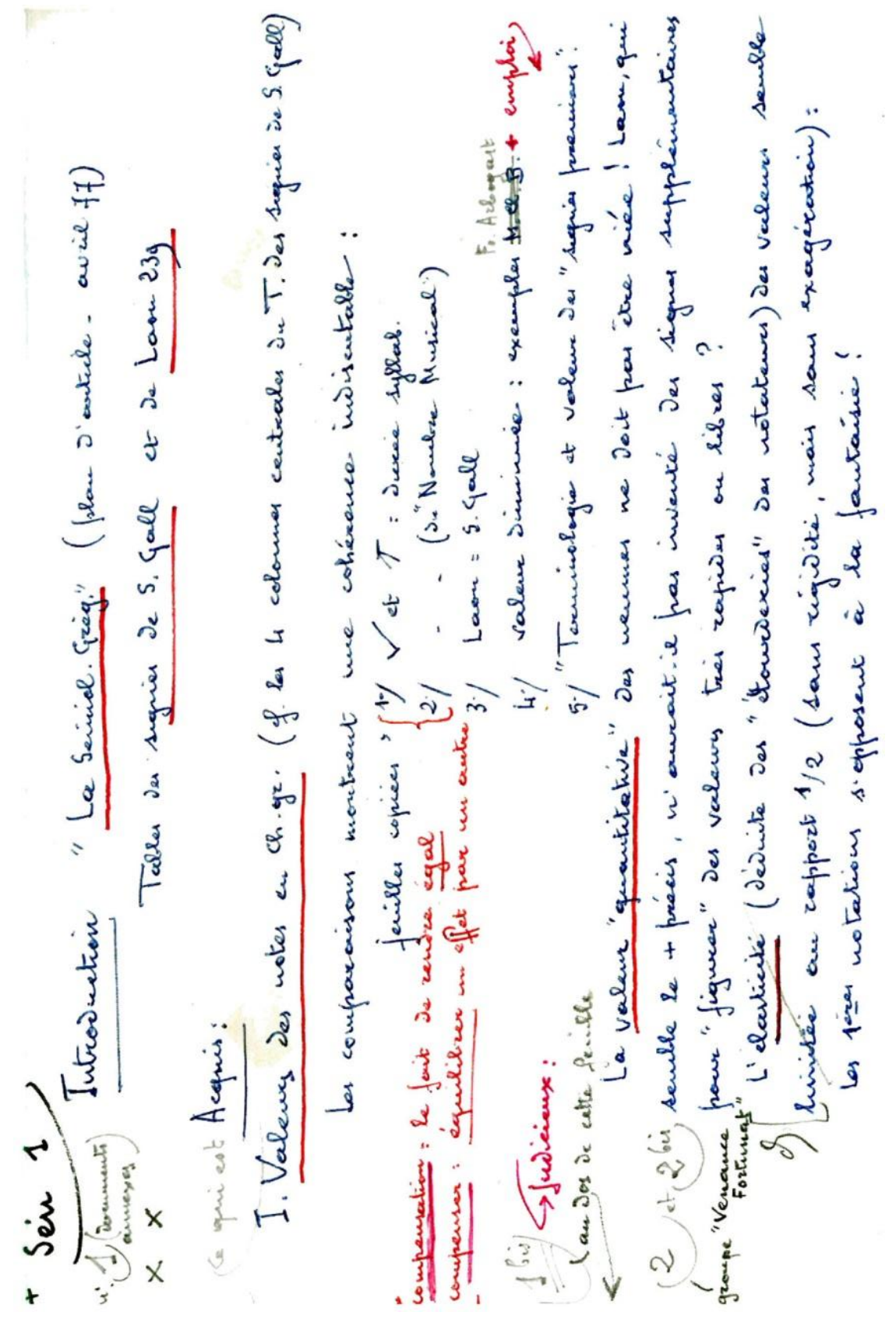

Zdjęcie 7. Notatki dom Cardine'a do Sémiologie grégorienne 
mogli zrozumieć i zaakceptować semiologiczne innowacje, dla reszty ich współbraci były one niewykonalne.

O jakich innowacjach mówimy? Duża ich część oparta była bezpośrednio na wnioskach z badań nad neumami. Dla wielu - także dla mnie po pięciu latach spędzonych w dzieciństwie jako kantor w chłopięcym chórze hiszpańskiego klasztoru benedyktyńskiego należącego do kongregacji solesmeńskiej - był to pierwszy kontakt z neumami pochodzącymi z IX i X wieku. Było to coś całkiem nowego, ponieważ codzienny śpiew odbywał się z użyciem notacji kwadratowej i uważaliśmy, że jest to najstarsza notacja, w jakiej przekazany został repertuar. Tak więc pierwszym szokiem, pierwszą konsekwencją pracy Cardine’a i jego Semiologii było zmierzenie się z nieznanymi neumami. Do tego czasu z pewnymi wyjątkami interpretacja opierała się właśnie na samej kwadratowej notacji. Dwudzielne i trójdzielne rytmy były bardziej lub mniej łatwe do zidentyfikowania w notacji watykańskiej, ale w obserwacji czystych neum przestawało być to oczywiste. Dlatego Cardine z taką dokładnością dbał w swoich pismach o prawidłową identyfikację zapisów graficznych, które warunkowały proste ruchy, ale także innych. Zaprojektował kilka tabel, które w prosty sposób pozwalały zobaczyć, na przykładzie przynajmniej dwóch dawnych zapisów, na których pracował - z Sankt Gallen i Laon - neumy w czystej postaci i ich możliwe modyfikacje w zapisie przez dodanie litery lub epizem, przez ich charakter likwescencyjny, a co najważniejsze - przez ich połączenie zwane rozdzieleniem neumatycznym.

Termin „rozdzielenie” został czasem skojarzony z nazwą artykulacji. Być może sama nazwa „rozdzielenie” wprowadziła niektórych w błąd. Pamiętam wypowiedź wybitnego ucznia dom Cardine'a, że nawet gdyby jego mistrz nie zajmował się badaniami lub nie odkrył nic innego, tylko przez fakt obserwacji i zbadania zjawiska „rozdzielenia neumatycznego” i jego powszechnego użycia we wszystkich notacjach średniowiecznych - i bronię tu także jego występowania w polifoniach modalnych - już nawet tylko z tego powodu przeszedłby do historii muzykologii. W istocie, zgrupowania neum ustanawiające punkty rozpoczęcia i zakończenia ruchów melodycznych, wyrażone właśnie przez znak, który przerywa formę graficzną, są uważane za kluczowy element w interpretacji. Poszczególne pozycje tego rozdzielenia (na początku, w połowie wznoszenia lub opadania melodii, w nutach niskich, a nawet wysokich) pokazują, jak rytm dopasowuje się do tych nut, które są kluczowe dla zrozumienia gregoriańskiego dyskursu muzycznego. Jak już powiedzieliśmy, zjawisko to można zaobserwować we wszystkich znakach graficznych.

Pochodzę z Hiszpanii. Mamy tu własny, szczególny repertuar śpiewów hiszpańsko-wizygockich (mozarabskich), z którego przetrwało wiele tysięcy zapisanych utworów in campo aperto, ale które nigdy nie zostały zapisane w interwałach. Jednak obserwując te starohiszpańskie neumy, możemy zastosować badania 
Semiologii, podobnie jak uczynił to uczeń dom Cardine’a, a ostatni przez niego wypromowany doktorant, Herminio González Barrionuevo, zastosował semiologiczne kryteria do różnych pisowni rękopisów z północnej Hiszpanii ${ }^{22}$.

Kolejne zagadnienie dotyczy zróżnicowania w grupach, które wyrażają unisono. Być może to właśnie sam Cardine doprowadził do zastąpienia tego tak często niezrozumianego terminu przez określenie „rozwój melodyczny w unisonie”. I właśnie w tych grupach istnieje wyraźne „przed Semiologia” i „po Semiologii”. Widać to nie tylko w różnicowaniu znaków graficznych, ale i w ich wykonaniu - jak wiele zawdzięcza dom Cardine’owi tabela neum z Liber Hymnarius z 1983 roku! Cardine wykonał ogromną pracę, co można wyczytać wiele razy w jego Semiologii, obserwując metodę kopiowania przez średniowiecznego kopistę: Cardine wnioskował, że skryba podnosił pióro, aby napisać serię znaków w unisonie - czy to drobnych, czy nie - w wykonaniu powinna mieć miejsce pulsacja przy każdym z dźwięków. To zaś dotyczy już nie tylko znaków strophicus lub grupy virg, ale także trigon i wszystkich innych grup neumatycznych w unisonie. Zakonnik w oczywisty sposób odrzucił połączenie dwóch lub trzech nut, zaproponowane przez pierwotne rytmy solesmeńskie. Ten sposób interpretacji z lekkim pulsowaniem być może nie został zrozumiany przez niektórych wykonawców. Zawsze będę pamiętał komentarz, który usłyszałem osobiście od samego Cardine’a w lecie 1984 roku, gdy wędrowaliśmy przez teren opactwa. Odnosił się on do nagrania chóru chłopięcego z Montserrat intonującego responsorium Hodie nobis na Boże Narodzenie ${ }^{23}$.

Tak dotarliśmy do znaków graficznych będących elementem prowadzącym. Wystarczy spojrzeć na prace promowane przez dom Eugene Cardine'a, by zauważyć znaczenie, które solesmeński zakonnik przywiązywał w szczególności do owych elementów neumatycznych. Jego stanowisko było bardzo jasne, a interpretacja niektórych z tych neum zmieniła się radykalnie. Salicus jest tego najlepszym przykładem. Neuma ta, której środkowy element (przy formie trójdźwiękowej) jest nośnikiem ictusa w edycji watykańskiej oraz w poprzednich i kolejnych wydaniach z Solesmes, podwajała swoją wartość przy zastosowaniu rytmów dwui trójdzielnych. Otóż semiologiczne badania dotyczące tej neumy i jej centralnego

22 Możemy o tym przeczytać w wielu artykułach. Rozróżnił sálicus, scandicus, scandicus flexus, scandicus subbipunctis, a przede wszystkim w artykule opublikowanym w „Studi Gregoriani” 11 (1995), s. 5-112: Relación entre la notación mozárabe de tipo vertical y otras escrituras neumáticas (pl. Relacja między notacją mozarabska typu pionowego a innymi zapisami neumatycznymi).

23 Nagranie w: www.discogs.com/es/artist/2489540-Gregorian-4; Escolanía De Montserrat www. discogs.com/es/artist/3040560-Escolan\%C3\%ADa-De-Montserrat; Pater Gregori Estrada, Die Tradition Des Gregorianischen Chorals Responsoria Ad Matutinum In Nativitate Domini, Archiv, 1974, www.discogs.com/es/artist/1836743-Gregori-Estrada. 


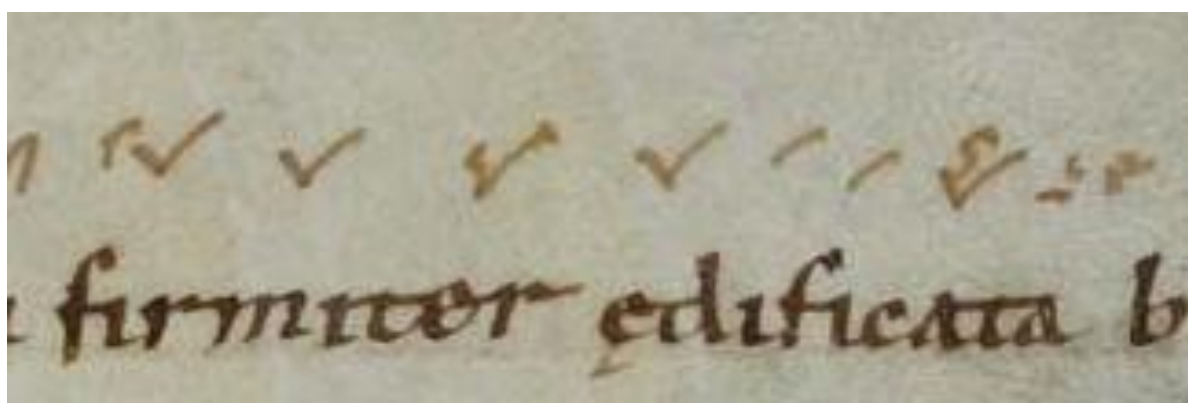

Zdjęcie 8. Seria podatus w A/ Haec est domus domini. Antyfonarz Hartkera, f. 329/9

elementu, oriscusa, wyraźnie pokazują, że owszem, jest to ważna nuta, ale dlatego, że prowadzi ruch ku kolejnej nucie, która pełni najistotniejszą rolę. Powołując się na ten argument, wykazano, że w kontekstach wnoszących ugrupowanie oriscus-virga zawsze skłaniano się ku tej drugiej nucie, podczas gdy pierwsza z nich była jedynie elementem prowadzących. Jest tak na przykład w antyfonie na poświęcenie kościoła Haec est domus Domini nad firmiter aedificata.

Działo się tak oczywiście także wtedy, gdy oriscus był częścią pressusa, jako że ruch dążył zawsze ku następnemu dźwiękowi, schodząc w tę nutę, której sinusoidalny znak graficzny również wskazywał ten efekt. Podobnie jest w konotacjach typu melodyjnego używających oriscus jako zwieńczenia znaku virga strata: w pozycji pesa o pół tonu oprócz prezentacji komponentów retorycznych lub też jako dwie nuty w unisonie w rzadko spotykanej skali. Przypominam sobie także komentarze o. Cardine’a dotyczące Communio na dzień Świętych Młodzianków (28 XII) Vox in Ramá... ululatus...

Te i wiele innych kwestii Semiologia omawia w sposób rozległy i doskonały, z licznymi przykładami, w których porównano różne przypadki obejmujące

Mt. 2, 18

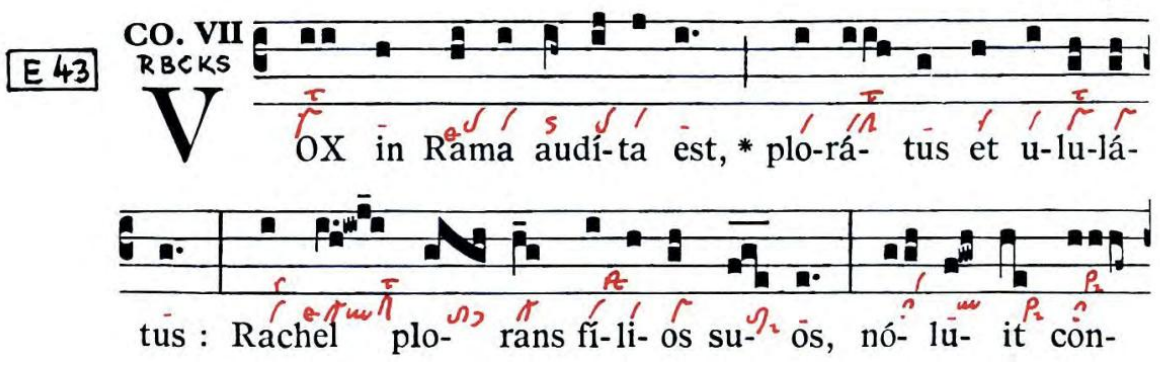


ponadto neumy nie tylko z Sankt Gallen, lecz również inne systemy notacyjne. Wiele z rozpraw dyplomowych i doktorskich zajmowało się właśnie zapisami $\mathrm{w}$ innych notacjach. Wykazano w ten sposób, że zastosowanie kryteriów semiologicznych można rozszerzyć na inne znaki graficzne, które przekazywały repertuar gregoriański. Dowodzą tego wybór skopiowanych neum rękopisu Laon 239 z Graduale Triplex (Solesmes 1979) oraz ustalenia niektórych prac dyplomowych, które analizowały neumy z tego manuskryptu.

Niniejszy artykuł świadomie poświęcony jest jedynie środowisku dom Cardine’a: staraniom opactwa Solesmes bezpośrednio poprzedzających jego dzieła oraz jego własnej, późniejszej pracy jako profesora Papieskiego Instytutu Muzyki Kościelnej zwieńczonej osiągnięciami, które znamy wszyscy, zawartymi w Semiologii gregoriańskiej. Jego teorie jednak miały i nadal mają wielu przeciwników. Niestety, prawdopodobnie nie poznali oni wystarczająco jego prac. Sam Cardine, pod koniec życia redagując swój testament, był świadomy, że w wielu przypadkach go nie rozumiano, a jego nauki mogą być błędnie interpretowane. $Z$ pewnością także nie istnieje jedna jedyna interpretacja śpiewu gregoriańskiego ${ }^{24}$. Nie istnieje ona obecnie, nie było jej także w średniowieczu. Potwierdzają to same rękopisy - dom Cardine twierdził podobnie. Chciał on jednak pozostawić nam pewną strukturę, gramatykę, abyśmy mogli wyrazić mowę zapisaną w neumach. Stworzył szkołę, która pozostała wierna jego naukom i która wyszła dalej, głębiej - sub umbra alarum suarum - na drogę, którą on sam podążał, zawsze jednak - jak mawiał jeden z jego poprzedników - zachowując „szacunek dla sztuki doskonałej samej w sobie”25.

\section{Abstrakt \\ Badania nad śpiewem gregoriańskim przed Semiologią gregoriańska i po niej}

Badania nad chorałem gregoriańskim z połowy XIX wieku znalazły swoich protagonistów wśród kilku mnichów z Solesmes. Po pontyfikacie św. Piusa X, motu proprio i nowej edycji Watykanu styl Solesmes i Methode... rozprzestrzeniły się wszędzie, ale niektóre głosy

24 Les limites de la sémiologie en chant grégorien, „Études Grégoriennes” (1989) 23, s. 5-10, przetłumaczony także na inne języki.

25 Sentencja ta znajduje się pod zdjęciem Dom Mocquereau w Palèographie (klasztor w Solesmes). 
z klasztoru Solesmes mówiły o nowym podejściu do pisma muzycznego: neumes. Semiologia dom Cardine’a była nauką stworzoną, by odpowiedzieć na niektóre braki teorii Mocquereau. W artykule ukazany jest krótki zarys historyczny wcześniejszych prac na temat Semiologii Cardine’a, zwłaszcza opracowanych na podstawie poprzednich badań Paléographie musicale.

Stowa kluczowe: śpiew gregoriański XIX i XX wieku, restytucja śpiewu, paleografia muzyczna z Solesmes, edycja watykańska, semiologia gregoriańska

\begin{abstract}
The research on gregorian chant before and after the Cardine's Semiology

The research on gregorian chant from the middle of the 19th century had their protagonists mainly in some of the Solesmes monks, but not without polemics. After the St. Pius X motu roprio, and the new Vatican edition, the Solesmes style and Methode... was spread everywhere, but some voices, from the own monastery, claimed for a new approach to the musical writing: the neumes. Dom Cardine's Semiology was the science created to answer some of the the lacks of the Mocquereau's theories. In this paper I'll try to show a little history of the previous works to the Cardine's Semiology, specially the Cardine's own works developed from the previous researches of the Paléographie musicale.
\end{abstract}

Keywords: gregorian chant XIX-XX century, restoration of chant, Solesmes Paleógraphie Musicale, Vatican edition, Gregorian Semiology

\title{
Bibliografia
}

Bergeron K., Decadent Enchantments. The Revival of Gregorian Chant at Solesmes, Berkeley 1998.

Cardine E., L'édition critique du graduel. Nécessité, avantages, method, „Revue Grégorienne" (1950) 29.

Cardine E., Signification de la désagrégation terminale, „Revue Grégorienne” (1952) 31, s. 55-65.

Cardine E., Paroles et mélodie dans le chant grégorien, „Bollettino degli amici del PIMS” (1954) 6/3, s. 1-9.

Cardine E., Neumes et rythme, w: Actes du 3 e Congrés International de Musique Sacrée, (Paris, juillet 1957), Paris 1959, s. 264-276. 
Cardine E., Preuves graphiques du principe des “coupures” dans les neumes”, „Études Grégoriennes” (1961) 4, s. 43-54 et 6 planches.

Cardine E., Graduale neumé, Solesmes 1966.

Cardine E., Paleografia gregoriana, 1, Note raccolte dalle lezioni tenute da dom Eugène Cardine,Rome 1967.

Cardine E., Semiologia gregoriana, Rome 1968.

Cardine E., Primo anno di canto gregoriano, Rome 1970.

Cardine E., Les limites de la sémiologie en chant grégorien, „Études Grégoriennes” (1989) 23, s. $5-10$.

Combe P., Histoire de la Restauration du Chant Grégorien d'après des Documents Inédits. Solesmes et l'Édition Vaticana Solesmes 1969.

Gontier A., Méthode raisonnée de plain-chant, Le Mans 1859.

González Barrionuevo H., Relación entre la notación mozárabe de tipo vertical y otras escrituras neumáticas, „Studi Gregoriani” (1995) 11, s. 5-112.

Graduale Triplex, Solesmes 1979.

Guéranger P., Institutions Liturgiques, vol. I, Paris-Bruxelles 1840.

Fonti e paleografia del canto ambrosiano, ed. M. Huglo, L. Agustoni, E. Cardine, E. Moneta-Caglio, Milano 1956 (Archivio Ambrosiano, 7).

Jeannin J., Études sur le rhytme grégorien, Lyon 1925.

Jeannin J., Rhytme Grégorien, Réponse à Dom Mocquereau, Lyon 1927.

Mocquereau A., Examen des critiques dirigéés par Dom Jeannin contre l'École de Solesmes, Solesmes 1926.

Paléographie musicale. Les Mélodies Liturgiques ou recueil de Fac-similés phototypiques des principaux manuscrits de chant grégorien, ambrosien, gallican, mozárabe, avec préface explicative publiée par les Révérends Pères Bénédictins de l'Abbaje de Solesmes, Solesmes 1888.

Pothier J., Les Mélodies Grégoriennes d'après la tradition, Solesmes 1880.

Pothier J., Liber Gradualis, Solesmes 1883.

Pothier J., Directorium Chori, Solesmes 1884.

Wagner P., Einfhrung in Die Gregorianischen Melodien, 3 vols. Leipzig 1911-1921.

Wollaerts J. A., Rhytmic Proportions in Early Medieval Eclesiastical Chant, Leiden 1956 (2a ed. 1960). 